\title{
Homelessness, Poverty AND DISCRIMINATION: \\ Improving Public Health by REALISING HUMAN RIGHTS
}

\author{
PHILIP LYNCH*
}

[There are clear casual and consequential links between homelessness, poverty, discrimination and poor health. This article argues that the engagement of homelessness and health in a human rights framework enables effective identification of socio-economic determinants of ill health and creation of the enabling conditions necessary for good health. The article contends that the integration of human rights principles into health service development, implementation and delivery, focuses attention on the need for health services to be adequate, accessible, non-discriminatory and appropriately targeted. The article also contends that a human rights approach to homelessness, poverty and health also imposes obligations - and enables measurement - in relation to realisation of the right to health and interconnected human rights (including the right to adequate housing, the right to social security, the right to non-discrimination, the right to participation, and the right to human dignity and respect)] 


\section{INTRODUCTION}

On any given night, almost 100000 people experience homelessness across Australia while, on any given day, at least 1 million people across Australia live in poverty. People experiencing homelessness and poverty experience widespread discrimination.

There are clear causal and consequential links between homelessness, poverty, discrimination and poor public health outcomes. Ill health can cause, contribute to and exacerbate homelessness, poverty and susceptibility to discrimination. Similarly, homelessness, poverty and the incidence of discrimination can cause, contribute to and exacerbate ill health. Countering these relationships, however, there are also clear and consequential links between a state's respect for human rights and that state's success in addressing homelessness, poverty and discrimination and promoting public health.

Using the Health Act 1958 (Vic) as a framework for discussion, this article examines the relationship between homelessness, poverty, discrimination and public health and the utility of analysing and addressing these issues in a human rights framework. It argues that Australia's legislative and institutional frameworks for public health should enshrine the right to the highest attainable standard of health and recognise and respond to the social and economic determinants of health, with particular regard for the special needs of people experiencing financial and social disadvantage, by respecting, protecting and fulfilling human rights.

The article concludes that the promotion of public health requires that factors underlying poor health outcomes, including homelessness, poverty and discrimination, be identified and addressed through a range of legislative and institutional measures. It further concludes that the international human rights framework provides a useful and important framework to identify, monitor, assess and address such factors. Poverty and vulnerability to ill health can be significantly reduced by governmental implementation of obligations to respect, protect and fulfill human rights.

\section{Homelessness, Poverty and Public Health \\ A Introduction}

Homelessness and poverty are among the most serious socio-economic and health issues confronting Australia and Victoria.

There are strong associations between homelessness, poverty and poor public health outcomes. There are also clear correlates between discrimination against people experiencing homelessness or poverty and poor health outcomes. 


\section{B Homelessness in Australia and Victoria}

A person experiences homelessness when he or she does not have somewhere to live in security, peace and dignity. ${ }^{1}$ This includes: people sleeping rough, living in cars or squats; people in crisis accommodation or refuges; people living temporarily with friends or relatives; and people living in rooming houses without security of tenure. $^{2}$

On any given night, over 20000 people experience homelessness in Victoria and almost 100000 people experience homelessness across Australia. This includes over 14000 people sleeping rough or in squats, more than 14000 in crisis accommodation or refuges, almost 23000 in boarding houses, and nearly 49000 people staying temporarily with friends of relatives. A further 23000 people across Australia live temporarily in caravan parks. ${ }^{3}$ Every day, more than 700 people are turned away from homelessness assistance services due to lack of capacity. ${ }^{4}$

The causes of homelessness are complex and varied. However, they are generally acknowledged to include structural causes (such as poverty, unemployment and inadequate supply of affordable housing $)^{5}$ and fiscal, social and public policy causes (such as taxation policy and expenditure on public and community housing, health care, education and vocational training). They also often include inter-related individual causes (such as ill health, mental illness, intellectual disability, substance and alcohol dependency, problem gambling, domestic violence, family fragmentation and severe social dysfunction) and cultural causes (such as the provision of culturally inappropriate housing or support services to indigenous communities) ${ }^{6}$

In many cases of homelessness, these causes are intersectional and related, although the common connecting factor tends to be poverty. ${ }^{7}$ For, while poverty does not always cause people to become homeless, it certainly renders them more vulnerable to homelessness when faced by other crises or setbacks. ${ }^{8}$

In addition to those experiencing homelessness, it is estimated that up to 35 per cent of low income people experience 'housing stress', meaning that their housing costs

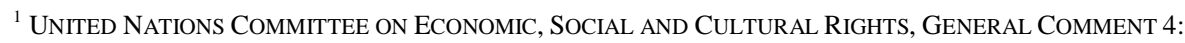
The Right to Adequate Housing, UN Doc HRI/GEN/1/Rev.5 (2001) 22. See also Supported Accommodation Assistance Act 1994 (Cth) s 4.

${ }^{2}$ Chris Chamberlain and David MacKenzie, Understanding Contemporary Homelessness: Issues of Definition and Meaning, 27 AUSTRALIAN JOURNAL OF SOCIAL ISSUES 274 (1992).

${ }^{3}$ Australian Bureau of Statistics, Counting the Homeless 2001 (2003).

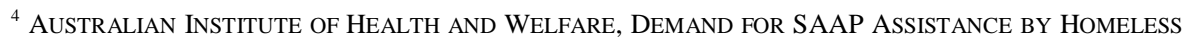
PEOPLE 2001-02 (2003).

${ }^{5}$ Following the 2001 Census, the Australian Bureau of Statistics identified unemployment and inadequate income as significant structural factors contributing to and causing homelessness across Australia: AUSTRALIAN BUREAU OF STATISTICS, supra note 3, 2001.

${ }^{6}$ See generally, The Changing Face and Causes of Homelessness: Symposium, 15(9) PARITY (2002).

${ }^{7}$ Jonathan L HAFETZ, Homeless Legal Advocacy: New Challenges and Directions for the Future, 30 FORDHAM URBAN L. J. 1215, 1222-3 (2003).

${ }^{8}$ Id. at 1223 .
} 
are so great relative to their income as to jeopardise their ability to meet other basic needs. Almost 10 per cent of low income people experience 'extreme housing stress', meaning that they are required to spend more than 50 per cent of their income on rent to avoid homelessness. ${ }^{9}$

\section{Poverty in Australia and Victoria}

While it is difficult to identify a universally accepted definition of poverty, ${ }^{10}$ there is an emerging consensus that poverty should be understood as a violation of human dignity arising from a deprivation of resources, capabilities, freedoms and choices necessary for the enjoyment of an adequate standard of living. ${ }^{11}$ According to the UN World Summit for Social Development poverty is characterised by and arises from

lack of income and productive resources sufficient to ensure sustainable livelihood; hunger and malnutrition; ill health; limited or lack of access to education and other basic services; increased morbidity and mortality from illness; homelessness and inadequate housing; unsafe environments; and social discrimination and exclusion. It is also characterised by a lack of participation in decision-making and in civil, social and cultural life. ${ }^{12}$

This definition of poverty encompasses not only the concept of 'income poverty' or 'income deprivation', but also broader factors or deprivations that can contribute to an impoverished standard of living, including poor housing, poor education, poor health, discrimination, vulnerability and social exclusion. ${ }^{13}$ The UN Committee on Economic, Social and Cultural Rights 'holds the firm view that poverty constitutes a denial of human rights'. ${ }^{14}$

According to a March 2004 Senate report on poverty and financial hardship, there are at least 1 million people across Australia living in poverty, although most indicators and studies suggest that this number is more likely between 2 and 3.5 million people. ${ }^{15}$

\footnotetext{
${ }^{9}$ Senate Community Affairs References Committee, A Hand Up Not a Hand Out: Renewing THE FIGHT AGAinst POVERTY 123-4 (2004).

${ }^{10}$ A recent Senate Committee inquiry into poverty and financial hardship devoted 27 pages to discussion of the definition of 'poverty': SENATE COMMUNITY AFFAIRS REFERENCES COMMITTEE, supra note 9, at $5-32$.

${ }^{11}$ Committee on Economic, Social and Cultural Rights, Substantive IsSues Arising IN THE IMPLEMENTATION OF THE INTERNATIONAL COVENANT IN ECONOMIC, SOCIAL AND CULTURAL RIGHTS: POVERTY AND THE ICESCR, UN DOC E/C.12/2001/10, 2-3, [7]-[8]; (2001); WORLD SUMMIT FOR SOCIAL Development, Programme of Action (1995) [19]. See also Amartya Sen, Development as FREEDOM (1999).

${ }^{12}$ WORLD SUMMIT FOR SOCIAL DEVELOPMENT, Id at 19.

${ }^{13}$ COMMITTEE ON ECONOMIC, SOCIAL AND CUltural Rights, supra note 11 at [7]-[8]

${ }^{14} I d$. at $1,[2]$.

${ }^{15}$ SENATE COMmunity AFFAIRs REFERENCES COMmitTEE, supra note 9, at xv-xvi.
} 
While poverty must be recognised as more than mere income deprivation, it is nevertheless the case that income inadequacy is a significant contributor to people either living in or being at risk of poverty. Despite this, across Australia, there is no guaranteed minimum income and social security payments are pegged well below the Henderson Poverty Line. According to the Australian Council of Social Service, in September 2002, the base rate of Newstart for a single unemployed adult person was paid at 63 per cent of the Henderson Poverty Line, rising to 78 per cent if the person also received the highest payable rate of rent assistance. For an unemployed young person living independently, the highest rate of payment, including rent assistance, amounts to 67 per cent of the Poverty Line. At the highest end, for a single person with a disability, the base rate of Disability Support Pension was paid at 89 per cent of the Henderson Poverty Line, rising to 108 per cent if the person was also paid rent assistance at the highest rate. ${ }^{16}$

A further contributor to poverty is discrimination. According to the Committee on Economic, Social and Cultural Rights, 'discrimination may cause poverty, just as poverty may cause discrimination'. ${ }^{17}$ The interrelationships of poverty, discrimination and public health are discussed further below.

\section{The Relationship between Homelessness and Public Health}

There are strong associations between homelessness and ill health.

Ill health is both a cause and consequence of homelessness. ${ }^{18}$ For example, Ill health can cause homelessness by reducing a person's capacity to obtain or maintain an adequate income. ${ }^{19}$ Similarly, mental health problems can cause family fragmentation and loss of the social and economic supports necessary to maintain stable housing. Identified health-related consequences of homelessness include low self-esteem, social isolation and mental health problems. ${ }^{20}$ In addition, homeless people experience significantly higher rates of death, disability and chronic illness than the general population but have less access to health services. ${ }^{21}$

According to recent studies, homeless people experience significantly higher rates of death, disability and chronic illness than the general population. ${ }^{22}$ Identified chronic health issues for people experiencing homelessness include blood borne viruses (particularly Hepatitis B and C), skin infections, cardiovascular disease,

\footnotetext{
${ }^{16}$ AUSTRALIAN COUNCIL OF SOCIAL SERVICE, FAIRNESS AND FlEXIBILITy 41 (2003).

${ }^{17}$ COMMITTEE ON ECONOMIC, SOCIAL AND CUlTuRAL RIGHTS, supra note 11, at 3 .

${ }^{18}$ Adrienne Lucy, South Eastern Sydney Area Health Service Homelessness Health Strategic Plan 2004-

09, 17 PARITY, 6 (2004).

${ }^{19}$ SENATE COMmunity AFFAIRS REFERENCES COMMITTEE, supra note 15 at 173.

${ }^{20}$ Lucy, supra note 18 at 6,7 .

${ }^{21}$ Perspectives on Health INEQuity (Elizabeth Harris, Peter Sainsbury and Don Nutbeam eds., 2000).

${ }^{22}$ Id; Lucy, supra note 18, at 6, 7.
} 
depression, post-traumatic stress disorder, malnutrition, dental decay and tooth loss. ${ }^{23}$

Notwithstanding the particular vulnerability of people experiencing homelessness to ill health, homeless people have significantly less access to health services than the broader population. ${ }^{24}$ The Senate inquiry into poverty and financial hardship found that homeless people 'miss out on a range of health services' ${ }^{25}$ As one formerly homeless person reports:

I was assaulted several years ago while having no fixed address. I was admitted to the Accident and Emergency department of a major hospital bruised and battered and with two sprained ankles. There was no avenue for effective after care. Who has ever heard of a hospital admission for sprained ankles! For somebody with a safe and secure home, limited use of both legs can be a major inconvenience. For somebody who has no secure home, limited use of their legs can be a serious threat to their continued well-being. ${ }^{26}$

Barriers to access include: lack of affordability for people experiencing financial hardship ${ }^{27}$ the inability or refusal of services to treat people experiencing comorbidity (that is, both mental health issues and drug or alcohol dependency) $;^{28}$ discrimination against, and exclusion of, people exhibiting 'problematic' behaviours (even where those behaviours are a manifestation of the underlying condition or illness); ${ }^{29}$ and lack of service capacity or supply. ${ }^{30}$ Lack of access to appropriate and affordable health care is often exacerbated by reluctance on the part of many homeless people to engage with services due to previous negative experiences, such as involuntary detention and treatment. ${ }^{31}$

\footnotetext{
${ }^{23}$ Lucy, supra note 18 , at 6, 7. See also Royal District NuRsing SeRvice Homeless Persons Program, A FrameWork: IMPROVING HEALTH OUTCOMES FOR PEOPLE EXPERIENCING HOMELESSNESS IN Victoria (1999), cited in DEPARTMENT OF HUMAN SERVICES, ViCTORIA, PRIMARY and Acute Health Responses to People Who ARe Homeless or at Risk of Homelessness: INFORMATION PAPER (2000) 4; Sam Lees, Homelessness Health Issues, 17(8) PARITY 30, 30 (2004).

${ }^{24}$ Harris, Sainsbury \& Nutbeam, supra note 21.

${ }^{25}$ SENATE COMMUNITY AFFAIRS ReFERENCES COMMITTEE, supra note 15 at 174.

${ }^{26}$ Matt Gleeson, Obstacles to Surviving Homelessness, 13(10) PARITY 7, 7 (2000).

${ }^{27}$ HOUSE OF REPRESENTATIVES STANDING COMMITTEE ON FAMILY AND COMMUNITY AFFAIRS, supra note 15 at $79-81$.

${ }^{28}$ HOUSE OF REPRESENTATIVES STANDING COMMITTEE ON FAMILY AND COMMUNITY AFFAIRS, $i d$ at 7981.

${ }^{29}$ House of Representatives Standing Committee on Family and COMmunity AfFairs, id at 79-81; Join Together, Ending Discrimination Against People with Alcohol and Drug PROBLEMS: RECOMMENDATIONS FROM A NATIONAL POLICY PANEL 3 (2003).

${ }^{30}$ House of REPRESENTATIVES STANDing COMmitTEE ON FAMILY AND COMMUNity AFFairs, supra note 15, at 158; Senate Legal and Constitutional Legislation Committee, Parliament of Australia, PROVISIONS OF THE DisABILITY DisCRiminATION AMENDMENT BILL 2003, 31 (2004).

${ }^{31}$ Roy al District Nursing Service Homeless Persons Program, it CAN Be Done: Health Care For People Who are Homeless (1992), cited in Department of Human SERVices Department of
} 
Research and experience demonstrate that improving health outcomes for homeless people requires specifically targeted health care services, delivered together with programs to address underlying causes of homelessness. ${ }^{32}$ Despite this, neither Australia nor Victoria has a homelessness action plan, a homelessness health strategy, or adequately funded and appropriately targeted health care services for homeless people.

\section{E The Relationship between Poverty and Public Health}

There are similarly strong links between poverty and ill health. Socio-economic status is a critical determinant of health status, with lower socio-economic status generally associated with poorer overall health. ${ }^{33}$

Poor health plays a central role in creating, exacerbating and perpetuating poverty. Evidence tendered to the Senate inquiry into poverty and financial hardship demonstrated that poor health can cause poverty (by, for example, reducing a person's capacity to engage in employment or education) and maintain poverty (by, for example, requiring a family to sacrifice basic needs to meet health care costs). ${ }^{34}$ As one witness to the Senate inquiry testified:

I have got no health care for my children. I dread every sniffle and cough because I cannot afford to go to the doctor and, if I do go to the doctor, I cannot afford to pay for the prescriptions that they are going to need when I am finished. We may be at the top end of the poverty scale but we are on the downward slide and, if something is not fixed, then that is where we will end up. ${ }^{35}$

Similarly, poverty tends to have a very negative overall impact on public health. Substantial statistical analysis demonstrates that the most critical determinants of a population's life expectancy, a key indicator of public health, are public expenditure on health care and the success of poverty alleviation strategies, including targeted health care programs for the disadvantaged and social security and safety net arrangements. ${ }^{36}$ Despite this, neither Australia nor Victoria has an anti-poverty strategy or a targeted and comprehensive health care program for people experiencing poverty. Further, there is no national or statewide program to ensure the conditions necessary for health, including access to adequate housing, nutrition, income support and health and medical services.

Human Services, Victoria, Primary and Acute Health Responses to People Who Are HOMELESS OR AT RISK OF HOMELESSNESS: INFORMATION PAPER 3 (2000).

${ }^{32}$ Paula Braveman \& Sofia Gruskin, Poverty, Equity, Human Rights and Health, 81(7) BULLETIN OF THE WORLD HEALTH ORGANIZATION 539, 540 (2003).

${ }^{33}$ SENATE COMMUNITY AFFAIRS REFERENCES COMMITTEE, supra note 15, at 173. See generally CHRIS REYNOLDS, PUBliC HEALTH LAW IN AUSTRALiA (1995).

${ }^{34}$ SenAte COMmunity AFFAIRS REFERENCES COMMITTEe, $i d$ at 173.

${ }^{35}$ Id. at 174

${ }^{36}$ Sudhir Anand and Martin Ravallion, Human Development in Poor Countries: On the Role of Private Incomes and Public Services, JOURNAL ECONOMIC PERSPECTIVES 7 (1993); Sen, supra note 11, at 44-7. 


\section{F Links between Discrimination Against People Experiencing Homelessness or Poverty and Public Health}

There are strong links between discrimination against people experiencing homelessness or poverty and the health status of those groups. ${ }^{37}$ According to the World Health Organization:

The fundamental principles of equality and freedom from discrimination have been identified as key components in all matters concerning health. This includes non-discrimination in access to health facilities, goods and services, paying particular attention to the most vulnerable or marginalised sections of the population. ${ }^{38}$

The World Health Organization considers that 'discrimination violates one of the fundamental principles of human rights and often lies at the root of poor health status'. ${ }^{39}$ This view is consistent with an emerging consensus that discrimination and stigmatization are major causal factors of ill health, including higher anxiety, depression, worsened quality of life, a sense of loss of control and difficulty coping. ${ }^{40}$ As St Mary's House of Welcome, a drop-in centre in Fitzroy, Victoria for people experiencing homelessness identifies:

Our service users include homeless people, people in financial crisis, people who are suffering hardship, people with alcohol, drug and gambling addictions, mentally ill people and others of low social status. They experience discrimination because of their social status, their appearance and their lack of access to amenities and services. The effect of this discrimination can be detrimental to health and well-being, result in further financial hardship, and impact negatively on ability to cope. ${ }^{41}$

Discrimination can exclude people from access to good and services, health care, adequate housing, education and employment, all of which are powerful influences on and determinants of public health. ${ }^{42}$ Discrimination can also increase

\footnotetext{
${ }^{37}$ See, for example, Sofia Gruskin, The Integration of Human Rights into Public Health Programming 1(Paper presented at the International Symposium on Human Rights in Public Health: Research, Policy and Practice, The University of Melbourne, 3-5 November 2004).

38 WORld HEAlth ORganization, HEAlth AND FREEDOM From Discrimination: WHO'S CONTRIBUTION TO THE WORLD CONFERENCE AGAINST RACISM, RACIAL DisCRIMINATION, XENOPHOBIA AND RELATED INTOLERANCE 12 (2001).

${ }^{39}$ Id., at 6.

${ }^{40}$ Lisa Waller, Living with Hepatitis C: From Self-Loathing to Advocacy, 180 MedICAL JouRnal OF Australia 293 (2004); S Zickmund, E Y Ho, M Masuda et al, They Treated Me Like a Leper: Stigmatization and the Quality of Life of Patients with Hepatitis C, 18 JOURNAL G.I MEDICINE 835 (2003).

${ }^{41}$ LeTter From St MARY's House of Welcome to THE PILCH HOMELESS PERSONS' LeGal CliniC DATED 20 AUGUST 2002.

${ }^{42}$ Braveman \& Gruskin, supra note 32, at 539.
} 
vulnerability to or magnify poverty, leading to ill health. ${ }^{43}$ Indeed, according to Jesuit Social Services:

Discrimination, especially in the areas of private housing, room and caravan rental, and also in health, is both widespread and can result in significant psychological deterioration as well as material deprivation of the recipient. Indeed, consistent discrimination of this nature results in deepening of identification with the marginalised condition so as to make negotiation through their issues more difficult. ${ }^{44}$

Despite the clear correlates between discrimination, poverty and public health outcomes, discrimination against people experiencing homelessness or poverty, including in the provision of health and medical services, is not only widespread in Victoria and at a national level, it remains lawful. ${ }^{45}$ At a state level, the Equal Opportunity Act 1995 (Vic) does not prohibit discrimination on the ground of social status, homelessness, poverty, unemployment or on the basis that a person is a recipient of social security or welfare assistance. This lack of legal protection from discrimination causes and contributes to homelessness, poverty and poor public health outcomes.

\section{Public Health and Human Rights}

\section{A Introduction}

There is a strong positive correlation between a state's respect for human rights and that state's success in addressing poverty and promoting public health, with the realisation of human rights ensuring the underlying enabling conditions of good health. ${ }^{46}$ As the Word Summit for Social Development recognises in its Programme of Action, the satisfaction of basic human needs and the realisation of basic human rights are essential elements of poverty reduction and public health promotion. The Programme of Action stipulates that these needs and rights are "closely interrelated and comprise nutrition, health, water and sanitation, education, employment, housing and participation in cultural and social life'. ${ }^{47}$

This section discusses the normative content of the right to health and the obligations imposed on governments to realise the right to health. It then discusses

\footnotetext{
${ }^{43}$ WORLD HEALTH ORGANIZATION, supra note 38 , at 10 .

${ }^{44}$ LetTer From Jesuit Social Services to PILCH Homeless Persons' Legal Clinic Dated 22 AUGUST 2002.

${ }^{45}$ Philip Lynch and Bella Stagoll, Promoting Equality: Homelessness and Discrimination, 7 DEAKIN L. REV. 295 (2002).

${ }^{46}$ See generally, SEN, supra note 11, at 49, 87, 90 and 144. See also Dianne Otto, Linking Health and Human Rights: What are the Possibilities? 11 (Paper presented at the International Symposium on Human Rights in Public Health: Research, Policy and Practice, University of Melbourne, 3-5 November 2004).

${ }^{47}$ WORLD SUMMIT FOR SOCIAL DEVELOPMENT, supra note 11, [35].
} 
the interrelationship between the realisation of human rights and the promotion of public health and the importance of contextualising and addressing issues of homelessness, poverty and discrimination by reference to the international human rights framework.

\section{B The Right to the Highest Attainable Standard of Health}

Pursuant to article 12 of the International Covenant on Economic, Social and Cultural Rights, all people have the right to the highest attainable standard of physical and mental health. ${ }^{48}$

Although the right to health does not necessarily translate as a right to 'be healthy' (the UN Committee on Economic, Social and Cultural Rights acknowledges that health is relative to an individual's biological conditions and a state's available resources), ${ }^{49}$ the right does impose important substantive obligations on States Parties to the Covenant to establish conditions, designed to ensure that people have the best possible chance of being healthy. According to the Committee, these conditions should mean that people are able to access the full variety of facilities, goods, services and conditions necessary to ensure an individual's health. ${ }^{50}$ This includes access to appropriate health care and also access to safe water, adequate sanitation, an adequate supply of safe food, adequate nutrition, adequate housing, occupational health, a healthy environment and access to health-related information. $^{51}$ Services must be provided in a culturally appropriate ${ }^{52}$ and nondiscriminatory manner. ${ }^{53}$

Article 2(1) of the ICESCR sets out the implementation obligations imposed on States Parties to the Covenant. Relevantly, it provides that States Parties must take steps, using the maximum available resources, to progressively achieve the full realisation of the human rights contained in the Covenant, including, particularly, through the adoption of legislative measures. According to the Committee, the steps and measures taken must be 'deliberate', 'concrete' and 'targeted as clearly as possible' towards full realisation of the right to the highest attainable standard of health. ${ }^{54}$ Progress towards full realisation of the right is required to be as 'expeditious' and 'effective' as possible and requires that the maximum of available resources be directed towards public health, including by ensuring that the attainment of public health is a fiscal and budgetary priority. ${ }^{55}$ Further, even while Stets Parties are developing and implementing measures for the full realisation of the highest attainable standard of health, they are under a 'core obligation' to ensure

\footnotetext{
${ }^{48}$ Opened for signature 16 December 1966, 993 UNTS 2 (entered into force generally 3 January 1976 and for Australia 10 March 1976)

${ }^{49}$ CommitTee ON ECONOMic, Social AND Cultural Rights, supra note 11, [9].

${ }^{50}$ Id. $4,[9]$,

${ }^{51} I d .[11]$.

${ }^{52}$ Id. [27] [37].

${ }^{53} I d$. AT 43(A).

${ }^{54}$ COMmitTEE ON ECONOMic, SOCial AND CUltural Rights, GENERAL COMMENT 3: THE NATURE OF STATES' PARTIES OBLIGATIONS, UN DOC HRI/GEN/1/REV.5 (2001) 18.

${ }^{55} I d$. at $18,[9]$.
} 
that certain non-derogable 'minimum essential standards' relating to the right to health are met, including in relation to the provision of basic housing, nutrition and health care for marginalised or disadvantaged people. ${ }^{56}$

\section{The Relationship between the International Covenant on Economic, Social and Cultural Rights and Australian Domestic Law and Arrangements}

Australia became a State Party to the ICESCR in 1976. In so doing, Australian governments at a national, state and local level committed to, and became responsible for, the implementation of measures to progressively realise the right to the highest attainable standard of health, among other rights. ${ }^{57}$

Unfortunately however, although ratified, the ICESCR has not been enacted at a federal or state level as part of Australian domestic law, meaning that its provisions do not confer directly enforceable legal rights in Australia. Although ratified but unincorporated treaties are not self-executing in Australia, that does not mean that international human rights standards have no bearing on domestic law or policy or, to use the words of the High Court, that ratification of an international human rights treaty such as the ICESCR or the International Covenant on Civil and Political Rights is a merely 'platitudinous' act. ${ }^{58}$ Ratified but unincorporated treaties may have a powerful bearing on the development of the common law, ${ }^{59}$ the interpretation and application of legislation ${ }^{60}$ (and possibly the Constitution), ${ }^{61}$ the implication of Constitutional guarantees,${ }^{62}$ the exercise of judicial discretions, ${ }^{63}$ and the making and review of administrative and executive decisions. ${ }^{64}$

Most importantly, however, ratification of an international human rights instrument such as the ICESCR is a 'positive statement' that 'the executive government and its agencies will act in accordance with the Convention'. ${ }^{65}$ As a matter of international

\footnotetext{
${ }^{56} I d$. at 18, [10] COMMITTEE ON ECONOMic, Social AND CUltURAL Rights, supra note 11, at 4.

${ }^{57}$ Article 28 of the ICESCR expressly provides that "In federal States Parties to the Covenant, implementation of the rights contained therein must extend to all parts of that state regardless of its federal or constitutional structure". See also Human Rights Committee, General Comment 31: Nature of the General Legal Obligation Imposed on States Parties to the Covenant, UN DOC CCPR/C/21/REV.1/ADD13, [4] (2004).

${ }^{58}$ Minister of State for Immigration and Ethnic Affairs v. Teoh, (1995) 183 CLR 273, 291 (Mason CJ and Deane J)

${ }^{59}$ Mabo v. Queensland, (1992) 175 CLR 1, 42.

${ }^{60}$ Polites v. Commonwealth, (1945) 70 CLR 60.

${ }^{61}$ Newcrest Mining Ltd v. Commonwealth, (1997) 190 CLR 513, 661.

${ }^{62}$ Coleman v. Power, [2004] HCA 39 (1 September 2004).

${ }^{63}$ Dietrich v. Queen, (1992) 177 CLR 292.

${ }^{64}$ Minister of State for Immigration and Ethnic Affairs v. Teoh, (1995) 183 CLR 273, 291 (Mason CJ and Deane $\mathrm{J}$ ).

${ }^{65}$ Minister of State for Immigration and Ethnic Affairs v. Teoh, (1995) 183 CLR 273, 291 (Mason CJ and Deane J).
} 
law and principle, federal state and local legislative frameworks and institutions for public health should, at a minimum, be consistent with international human rights standards and commitments.

\section{The Role of Human Rights in Addressing Poverty and Promoting Public Health}

As discussed above, there is a strong positive correlation between a state's respect for human rights and that state's success in addressing poverty and promoting public health. ${ }^{66}$

The international human rights framework provides a useful and important framework to identify, monitor, assess and address the civil, political, economic, social and cultural determinants of poverty and ill health. Recognising these interconnections, the Committee on Economic, Social and Cultural Rights has stated that:

The right to health is closely related to and dependent upon the realization of other human rights ... including the rights to food, housing, work, education, human dignity, life, non-discrimination, equality, the prohibition against torture, privacy, access to information, and the freedoms of association, assembly and movement. These and other rights and freedoms address integral components of the right to health. ${ }^{67}$

Poverty and vulnerability to ill health can be significantly reduced by governmental implementation of obligations to respect, protect and fulfill human rights. ${ }^{68}$ According to former UN High Commissioner for Human Rights, Mary Robinson:

Respect for human rights, the standards of which are contained in numerous international instruments, is an important tool for protecting health. It is those who are most vulnerable in society - women, children, the poor, persons with disabilities, the internally displaced, migrants and refugees - who are most exposed to the risk factors which cause ill health. Discrimination, inequality, violence and poverty exacerbate their vulnerability.

It is therefore crucial not only to defend the right to health but to ensure that all human rights are respected and that the root economic, social and cultural factors that lead to ill health are addressed. ${ }^{69}$

\footnotetext{
${ }^{66}$ See generally, SEN, supra note 11, 87, 90, 144.

${ }^{67}$ Dianne Otto, Linking Health and Human Rights: What are the Possibilities? 8 (Paper presented at the International Symposium on Human Rights in Public Health: Research, Policy and Practice, University Melb, 3-5 November 2004).

${ }^{68}$ World HeAlth ORGANiZATION, supra note 38, at 6. See also B Loff, Reconciling Rights with Risk in Australian Institute of Health Law and Ethics, Public HeAlth LAw: New PERSPECTIVES 139 (1998).

69 Mary Robinson, UN High Commissioner for Human Rights, quoted in WORLD HEALTH ORGANIZATION, supra note 38, 7 (2001).
} 
The international human rights framework also imposes obligations on governments to develop and implement policies that provide all persons with the maximum opportunity to be healthy, including by addressing poverty and homelessness.

The interdependence and indivisibility of the international human rights framework makes it clear that while governments have obligations to respect and protect the right to health - including by preventing, treating and controlling disease and ensuring access to appropriate health care - they also have obligations to ensure the conditions required for fulfillment of public health. ${ }^{70}$ This requires that they progressively correct conditions that may impede realisation of the right to health - such as poverty and homelessness - as well as ensure that all people can access the goods and services necessary for good health, including through realisation of the right to adequate housing, the right to an adequate income or social security, the right to equality and freedom from discrimination, the right to privacy, the right to participation, the right to education and the right to dignity and respect.

\section{Reforming the Health Act 1958 to Address Poverty and Promote Public Health}

\section{A Introduction}

Improving public health requires not only improvements in the access that people experiencing homelessness, poverty or other forms of disadvantage have to health care, but that the conditions that cause, contribute to, or maintain homelessness and poverty are identified and addressed and that basic human rights are respected, protected and fulfilled.

This section discusses and proposes a range of reforms to Victoria's legislative and institutional frameworks for public health, particularly under the Health Act 1958.

\section{B Overarching Framework}

1 Scope and Objects of Legislative and Institutional Frameworks for Public Health

Given the strong associations and correlates between poverty, homelessness and ill health, federal and state legislative frameworks and institutions for public health must focus attention on and contribute to the alleviation of poverty.

Further, given the concomitance of the realisation of human rights with creation of the conditions necessary to ensure that people have the maximum opportunity to be healthy, it is imperative that legislative frameworks and institutions for public health enshrine the right to the highest attainable standard of health and contribute to the realisation of interrelated human rights.

\footnotetext{
${ }^{70}$ Braveman \& Gruskin, supra note 32 , at 539, 540 .
} 
In ratifying the ICESCR, Australian governments at a national, state and local level committed to, and became responsible for, the implementation of measures to progressively realise the right to the highest attainable standard of health, including by respecting, protecting and fulfilling related human rights. ${ }^{71}$ As discussed above, federal, state and local legislative frameworks and institutions for public health should, at a minimum, be consistent with international human rights standards and commitments.

Having regard to the above, the scope and objects of federal and state legislative frameworks for public health should include to:

- Respect, protect and fulfill the human right to the highest attainable standard of physical and mental health;

- Assist to respect, protect and fulfill the human rights necessary for full realisation of the right to the highest attainable standard of physical and mental health, including the right to freedom from discrimination, the right to adequate housing, the right to an adequate income or social security, the right to an adequate standard of living, the right to education, the right to privacy, the right to participation and the right to dignity and respect;

- Assist to identify and address civil, political, economic, social and cultural factors that contribute to health inequalities and ill health, including poverty and discrimination;

- Promote and protect public health and assist to prevent disease, illness, injury, disability and premature death; and

- Provide evidence-based information to the public about public health.

\footnotetext{
${ }^{71}$ See, for example, HUMAN Rights COMmitTEE, supra note 57, [4] which provides that:

The obligations of the Covenant in general and article 2 in particular are binding on every State Party as a whole. All branches of government (executive, legislative and judicial), and other public or governmental authorities, at whatever level - national, regional or local - are in a position to engage the responsibility of the State Party. The executive branch that usually represents the State Party internationally, including before the Committee, may not point to the fact that an action incompatible with the provisions of the Covenant was carried out by another branch of government as a means of seeking to relieve the State Party from responsibility for the action and consequent incompatibility. This understanding flows directly from the principle contained in article 27 of the Vienna Convention on the Law of Treaties, according to which a State Party 'may not invoke the provisions of its internal law as justification for its failure to perform a treaty'. Although article 2, paragraph 2, allows States Parties to give effect to Covenant rights in accordance with domestic constitutional processes, the same principle operates so as to prevent States parties from invoking provisions of the constitutional law or other aspects of domestic law to justify a failure to perform or give effect to obligations under the treaty. In this respect, the Committee reminds States Parties with a federal structure of the terms of article 50, according to which the Covenant's provisions 'shall extend to all parts of federal states without any limitations or exceptions.
} 


\section{$2 \quad$ Guiding Principles}

There is substantial evidence that public health policies are more likely to be 'effective, sustainable, inclusive, equitable and meaningful if they are based upon international human rights'. ${ }^{72}$ According to the Committee on Economic, Social and Cultural Rights, for this to occur, 'human rights need to be taken into account' in all relevant decision-making and policy formulation processes. ${ }^{73}$

In my view, it is imperative that public health legislation should contain Guiding Principles for any decision or order made under the enactment. Reflecting the proposed desired objects of public health legislation discussed above and the implementation obligations imposed on all levels of government and governmental instrumentalities under international human rights law, particularly the ICESCR, these Guiding Principles should include the following:

- $\quad$ Principle of realisation of human rights which recognises that respect for human rights promotes public health and requires that any decision or order be consistent with human rights norms;

- $\quad$ Principle of non-discrimination, which requires that, with the exception of 'special measures' designed to address disadvantage, discrimination on any ground (including, in particular, the ground of social or socioeconomic status) be prohibited $;^{74}$

- $\quad$ Principle recognising that socio-economic status is a critical determinant of health status; that civil, political, economic, social and cultural factors, including poverty and discrimination, contribute to health inequalities and ill health. Further, that any decision or order consider and address these factors $;^{75}$

- $\quad$ Principle recognising that social and economic disadvantage can impair access to health services or programs, and that public health policies and programs should be developed in such a way as to ensure appropriate access for people experiencing such disadvantage $;^{76}$ and

- $\quad$ Principle of participation requiring that persons affected or likely to be affected by a decision or order be consulted and provided the opportunity to participate in the decision-making process. Special measures may be required to ensure that impediments to participation, including

\footnotetext{
${ }^{72}$ COMMITTEE ON ECONOMIC, SOCIAL AND CUltural Rights, supra note 11, at 4.

${ }^{73} I d$. at 4

${ }^{74}$ This principle is consistent with the principle of non-discrimination contained in both the ICESCR (ART 2(2)) AND THE INTERNATIONAL COVENANT ON CIVIL AND POLITICAL RIGHTS (ARTS 2(1) AND 26).

${ }^{75}$ See generally, Braveman \& Gruskin, above n 32, at 541-3.

${ }^{76}$ Id. at 540. See also L A Aday and R M Andersen, Equity of Access to Medical Care: A Conceptual and Empirical Overview 19 MEDICAL CARE 4 (1981).
} 
homelessness, poverty and illiteracy, are identified and addressed as part of the consultation process. ${ }^{77}$

\section{Governmental Responsibilities, Intersectoral Relationships and Public Health}

\section{Responsibility for Implementation}

The attainment of public health requires extensive cooperation and collaboration between governments, government instrumentalities, the private sector, the community sector and individuals. It is important, however, that recognition of the roles of various stakeholders is accompanied by a clear statement of the responsibilities of those stakeholders.

International human rights law adopts a broad and flexible approach to measures required to be adopted by states in respect of the implementation of human rights, including the right to the highest attainable standard of health, so as to enable the legal and administrative structures of each state, as well as other relevant considerations, to be taken into account. ${ }^{78}$ Article 28 of the ICESCR makes specific reference to states with federal systems such as Australia, stating that 'the provisions of the present Covenant shall extend to all parts of federal states without limitations or exceptions'. The effect of this provision is to place primary responsibility with the federal government to 'ensure that the rights enumerated in the ICESCR are enjoyed throughout Australia', even where legal or administrative arrangements seek to delegate responsibilities in respect of the implementation of human rights to state or local governments, government instrumentalities, the private sector, the community sector and even to individuals. ${ }^{79}$ It is clear, however, that, under international law, Australia's 'collaborative' or 'cooperative' federal arrangements - whereby federal, state, territory and local governments, together with private and community sector actors, are entangled in complicated 'webs' of financial and bureaucratic relations - have resulted in a situation whereby state, territory and local governments have agreed to take on many of the obligations that are imposed by human rights treaties on Australia as a State Party, especially in the area of economic and social rights. ${ }^{80}$ That is, by negotiating a federal constitutional structure that defines federal and state domestic legal powers and responsibilities, state, territory and local governments have entered partnership or agency arrangements that make them accountable for implementing those of Australia's

\footnotetext{
${ }^{77}$ Human Rights Committee, General COMment 25: ARticle 25, UN DOC HRI/GEN/1/ReV.5, 158 (2001).

${ }^{78}$ Committee on Economic, Social and Cultural Rights, General Comment 9: The Domestic APPLICATION OF THE COVENANT, UN DOC HRI/GEN/1/REV (2001).

${ }^{79}$ Dianne Otto and David Wiseman, In Search of "Effective Remedies: Applying the International Covenant on Economic, Social and Cultural Rights in Australia, 7 Australian JOURnal OF Human RIGHTS, 22 (2001).

${ }^{80}$ See generally, VIENNA CONVENTION ON THE LAW OF TREATIES, OPENED FOR SIGNATURE 23 MAY 1969, 1155 UNTS 331 (ENTERED INTO FORCE 27 JANUARY 1980), ARTS 27, 46.
} 
international human rights obligations that fall within the scope of these arrangements. State, territory and local governments have directly assumed many international obligations through these domestic constitutional arrangements; these are obligations for which they can and should be held accountable under domestic legal and administrative processes. In the specific context of the right to the highest attainable standard of health, the sharing of international responsibilities is made abundantly clear by the role of states in enacting legislation and contracting with private and community sector entities so as to create the framework for public health and developing and implementing health care programs and policies.

Having regard to the above, as a matter of law and principle, public health legislation should clearly recognise that ultimate responsibility for public health lies with the federal and state governments. However, where a state government has delegated responsibility for some aspect of implementation of the right to the highest attainable standard of health, the relevant Act should clearly articulate the nature and extent of this delegation. This would aim to strengthen an agency's accountability for its decision making with reference to international human rights standards.

The provision of effective remedies is fundamental to the implementation of human rights obligations; those whose rights are violated must have access to a means of remedying or rectifying that violation. ${ }^{81}$ Under international human rights law, such remedies may be judicial, administrative or policy-based. Thus, public health legislation should provide access to effective remedies where the implementation of a responsibility under the Act has been insufficient or inadequate. Given that the ultimate responsibility for realisation of the right to the highest attainable standard of health lies with government, such remedies should be sought from and enforceable against the relevant government which could then, in turn, seek to recover any loss from the relevant entity where it related to a delegated responsibility under the Act.

\section{$2 \quad$ Partnerships in Public Health}

As discussed above, the promotion of public health requires that factors contributing to poor health outcomes, including homelessness, poverty, discrimination and inadequate realisation of human rights, be identified and addressed.

Although the health sector itself has limited control over socio-economic determinants of health, public health partnerships to develop and implement strategies that target those determinants have the potential to promote both public health and human rights.

In light of this, human rights-based public health legislation should recognise the importance of addressing socio-economic determinants of health — such as

\footnotetext{
${ }^{81}$ See generally, COMMitTEE ON ECONOMIC, SOCIAL AND Cultural Rights, supra note 57, at 18; COMMITTEE ON ECONOMIC, SOCIAL AND CULTURAL RigHTS, supra note 78, at 58.
} 
homelessness, poverty and discrimination — as part of any public health strategy. ${ }^{82}$ Such legislation should also promote cooperative research, analysis, and program design and implementation between the health sector and sectors involved in programs relating to human rights that bear on the right to health, such as the right to freedom from discrimination (eg, the Equal Opportunity Commission), the right to adequate housing (eg, the Office of Housing), the right to an adequate income or social security (eg, Centrelink), the right to education (eg, the Department of Education), the right to privacy (eg, the Privacy Commissioner), the right to participation, and the right to dignity and respect.

\section{Social Health Officers}

In Victoria, the Health Act 1958 (Vic) currently requires that municipal councils appoint Medical Officers of Health ('MOHs') and Environmental Health Officers ('EHOs") to provide advice and to assist in relation to health matters for both the Secretary and the council. Recognising the important role that these officers have played in the development and delivery of public health programs, particularly at a local level, in my view it is desirable that these functions should be retained in public health legislation.

However, given the very strong relationship between social and economic factors and public health, there is a strong argument that public health legislation should also require that municipal councils appoint a Social Health Officer ('SHO'). The powers of a SHO could include monitoring and assessing social and economic determinants of health, and providing assistance and advice on social and economic aspects of public health to the Secretary and the council.

\section{$4 \quad$ Commissioner for Public Health}

According to Dianne Otto, the human rights principles of accountability and the availability of effective remedies for human rights violations requires that public health frameworks include

independent and accessible internal complaints procedures, transparent and effective external review mechanisms and, to the greatest extent possible, legal implementation of the right to health that would ensure judicial review and enforceable remedies. ${ }^{83}$

Under the current Health Act 1958 (Vic) there is a clear conflict of interest between the Secretary's primary responsibility for implementing the Act and his or her power to conduct inquiries into matters of public health. This conflict arises because, in many cases, the Secretary will be required to inquire into his or her own policies, programs and procedures.

\footnotetext{
${ }^{82}$ Braveman and Gruskin, supra note 32 at, 541

${ }^{83}$ Otto, supra note 67, at 10 .
} 
Furthermore, under the current Health Act 1958 (Vic), there is no provision for the establishment of an independent investigatory or complaints resolution body in relation to matters of public health.

In my view, it is axiomatic to the promotion and protection of public health that public health legislation provide for the establishment of an independent statutory body, such as a Commissioner for Public Health, with broad powers to undertake investigations, handle complaints and render binding determinations. These powers could include the power to:

- Initiate and undertake investigations and inquiries regarding matters of public health and the extent to which the right to the highest attainable standard of health is protected, respected and fulfilled;

- Receive and consider complaints regarding matters of public health, including in relation to the extent to which the right to the highest attainable standard of health is protected, respected and fulfilled;

- Make determinations regarding matters of public health, including the extent to which the right to the highest attainable standard of health is protected, respected and fulfilled; and

- Make and enforce such orders as are necessary to improve or enhance public health, including by increasing the extent to which the right to the highest attainable standard of health is protected, respected and fulfilled.

Other functions of such a body could include:

- Educating the community about matters of public health, including the right to the highest attainable standard of health and social and economic determinants of health such as homelessness, poverty and discrimination; and

- Advising governments about matters of public health, including the right to the highest attainable standard of health and social and economic determinants of health such as homelessness, poverty and discrimination.

These proposed powers and functions are substantially similar to those conferred on the New South Wales Community Services Commission in respect of community services, which has recently been amalgamated with the New South Wales Ombudsman.

\section{Health Information}

The collection and effective dissemination of accurate and extensive public health information is necessary for a range of purposes, including identification of the nature, extent and causes of ill health and the determinants of good health and ill health, the development and implementation of policies and programs to improve public health, and so on.

Section 9 of the current Health Act 1958 (Vic) confers broad powers on the Secretary to collect, analyse, disseminate and utilise public health information. The 
retention of these powers is important. However, in my view, it is important that public health legislation also contain provisions which make more explicit the nature of certain forms of information that should be collected and the use that should be made of such information.

Significant research has demonstrated that while most public health efforts are intended to benefit the poor and vulnerable, 'a strategic approach is necessary to overcome the tendency for people experiencing poverty to benefit too little from even the best-intentioned public health programs' ${ }^{84}$ In this respect, the World Health Organization considers that,

at a minimum, this requires ongoing monitoring of social inequalities in health, receipt of health care, health care financing, and allocation of health care resources, with built-in mechanisms for translating findings into actions that fill the gaps. ${ }^{85}$

In relation to the collection, use and dissemination of health information, the World Health Organization recommends that:

Routine assessment of potential health implications for different social groups should become standard practice in the design, implementation and evaluation of all development policies ... Routinely collected data on health, health care and other health determinants that are monitored overall should also be disaggregated into more and less socially advantaged groups by factors such as wealth, gender and race/ethnicity that reflect poverty and social disadvantage.

$\cdots$

Quantitative data should be routinely supplemented by qualitative information from the poor and disadvantaged and their advocates describing unmet need, perceptions of service quality, and obstacles to receiving recommended services in any sector influencing health. ${ }^{86}$

In light of the above, it is crucial that the information-gathering provisions of public health legislation specifically provide that the entity responsible for the implementation and operation of the Act should collect, analyse, disseminate and utilise information about:

- Social and economic determinants of health;

- The relationship between financial and social disadvantage and health;

\footnotetext{
${ }^{84}$ Braveman and Gruskin, supra note, 32 at 539, 541; Paula Braveman and E Tarimo, SCREENING IN PRIMARY HEALTH CARE (1994).

${ }^{85}$ Braveman and Gruskin, id., at 539, 541.

${ }^{86}$ Id. at 539, 542. See also Dianne Otto, Linking Health and Human Rights: What are the Possibilities? 9 (Paper presented at the International Symposium on Human Rights in Public Health: Research, Policy and Practice, The University of Melbourne, 3-5 November 2004).
} 
- The relationship between discrimination and health;

- Systemic health disparities between social and economic groups and the causes of such disparities;

- Allocation of health care resources as between social and economic groups;

- Access to health care, including obstacles and barriers to accessing health care, for people experiencing financial or social disadvantage; and

- The relationship between public health and human rights, including the right to adequate housing, the right to an adequate income or social security, the right to equality and freedom from discrimination, the right to privacy, the right to participation, the right to education, and the right to dignity and respect. ${ }^{87}$

\section{$1 \quad$ Consultative Council on Poverty and Social Health}

The Health Act 1958 (Vic) provides for the establishment of a number of consultative councils comprising health professionals who are experts in the issues within the council's defined terms of reference. Existing councils include the Consultative Council on Obstetric and Paediatric Mortality and Morbidity, the Consultative Council on Anaesthetic Mortality and Morbidity, the Surgical Consultative Council and the Quality Assurance Committee. These councils play an important role in the continual evaluation and improvement of health services in Victoria.

Recognising the strong correlates between public health and social and economic well-being, it is desirable that public health legislation establish a Consultative Council on Social Health. The functions of such a council could include:

- To consider, investigate, monitor, analyse and report on the social and economic determinants of health, including poverty, homelessness and discrimination;

- To consider, investigate, monitor, analyse and report on programs directed towards improvement of the social and economic determinants of health, including programs directed to addressing poverty, homelessness and discrimination;

- To enhance programs directed towards improvement of the social and economic determinants of health by publication and dissemination of information and practical strategies identified by the Council;

- To regularly report to the Minister for Health;

\footnotetext{
${ }^{87}$ See generally Braveman and Gruskin, supra note 32, at 539.
} 
- To respond to matters referred by the Minister to the Council for investigation and reporting; and

- To produce an annual report on the work and deliberations of the Council and make recommendations for systemic change required to improve social and economic determinants of health and address issues of homelessness, poverty and discrimination.

A Consultative Council on Social Health could be conferred with the informationgathering powers necessary to discharge its functions, including a requirement that Social Health Officers report annually to the Council on the social and economic factors contributing to ill health and the programs directed towards addressing such factors.

\section{E Health Impact Assessments}

According to the World Health Organization:

Work on poverty, equity, human rights and public health must be integrated as an ongoing priority - rather than an afterthought or token concern - across programs. ${ }^{88}$

Public health is affected by diverse determinants, including civil, political, social, economic, cultural and environmental factors. Indeed, as Mary Mahoney argues, 'there is increasing international recognition that acknowledges that most of the major drivers of population health and the distribution of health lie outside that formal national health services and structures' ${ }^{89}$ In light of this, it is crucial to develop mechanisms and procedures by which the potential impacts of actions in the areas of other determinants of health, particularly social and economic areas, are monitored, considered and assessed.

Despite this, under the current Health Act 1958 (Vic) and related arrangements, the issue of public health is not routinely considered in the development and implementation of projects, programs and policies in many of these areas, despite their significant potential impact on public health. In my view this is a major deficiency that could be remedied, at least in part, by the enactment of provisions for the implementation of Health Impact Assessments ('HIAs'). HIAs, in this context, refer to

a combination of procedures, methods and tools by which a policy, program or project may be assessed and judged for its potential, and often unanticipated, effects on the health of the population, and the distribution of those effects within the population..$^{90}$

\footnotetext{
${ }^{88} I d$. at 541.

${ }^{89}$ Mary Mahoney, Health Impact Assessment (HIA) and Human Rights: Exploring the Connections, 3-4 (Paper presented at the International Symposium on Human Rights in Public Health: Research, Policy and Practice, University Melb, 3-5 November 2004).

${ }^{90} I d$. at $2 .$.
} 
Although public health impacts are routinely considered as a component of environmental impact assessments (EIAs), there is no mechanism for the consideration of the public health impacts of projects, programs or policies that fall outside the EIA framework.

In my view, HIAs could therefore play an important role in improving public health and promoting human rights by institutionalising the systematic and routine application of public health perspectives to both the health and non-health sectors. HIAs would provide an important tool pursuant to which the public health impacts of projects, programs and policies in both health and non-health areas, including housing, employment, education, income support and so on, could be identified, analysed and assessed..$^{91}$

\section{Further Measures to Address Poverty AND Promote Public Health}

\section{A Introduction}

As discussed above, there are clear causal and consequential links between homelessness, poverty and poor public health outcomes. There are also clear correlates between discrimination against people experiencing homelessness or poverty and poor health outcomes.

This section examines and discusses strategies to ensure that public health is improved through measures to reduce poverty, address homelessness, prohibit discrimination on the ground of social or economic status, and guarantee that all people are able to access the income support necessary to secure and sustain an adequate standard of living.

\section{B Anti-Poverty Strategy and Unit}

There is a very strong correlation between poverty and ill health on the one hand, and the alleviation of poverty, investment in targeted health care for the poor and improved public health on the other hand.

Recognising these links, the United Nations Committee on Economic, Social and Cultural Rights strongly recommends that each state develops and implements a 'participatory, multi-sectoral national anti-poverty program' that, at the very least, discharges the state's 'core obligations' in respect of the provision of 'minimum essential levels' of the rights to adequate housing, food, education and health. ${ }^{92}$ According to the Committee, the absence of such a program is likely, prima facie, to be 'inconsistent with the legally binding obligations of the State party' under the ICESCR..$^{93}$

\footnotetext{
${ }^{91}$ See generally Braveman and Gruskin, supra note 32, at 539.

${ }^{92}$ CommitteE ON ECONOMic, Social AND Cultural Rights, supra note 11, at, 4-5.

${ }^{93} I d$. at 4 .
} 
Despite this strong recommendation, neither Australia nor Victoria has an antipoverty strategy. There is no national or statewide program to ensure the conditions necessary for public health, including access as of right to adequate housing, nutrition, income support and health care and medical services.

Having regard to this, and consistently with the recommendations of both the Committee on Economic, Social and Cultural Rights and the Senate Community Affairs References Committee made pursuant to the recent inquiry into poverty and financial hardship, it is my view that federal and state governments should develop a comprehensive anti-poverty strategy that involves:

- Holding an initial summit of federal, state and local governments, the welfare sector, unions, the business sector, community groups, income support customers and relevant experts in the field to highlight the importance of the issue and agree on a timetable for action;

- A commitment to achieve a whole of government approach. That is, coordinated action across policy areas such as employment, health, education, income support, community services, housing and other relevant areas to reduce poverty and poverty of opportunity; and

- A consultation period of not longer than 12 months..$^{94}$

Also consistently with the recommendations of the Senate inquiry, it is my view that a statutory authority or unit reporting directly to the Prime Minister and state Premiers should be established with responsibility for developing, implementing and monitoring a national anti-poverty strategy and that this entity should:

- Establish benchmarks and targets to measure progress against a series of anti-poverty objectives;

- Report regularly to the Parliament on progress against the strategy; and

- Undertake or commission research into a range of poverty-reduction measures. ${ }^{95}$

\section{Homelessness and Health Action Plan}

As discussed above, there are strong links between homelessness and ill health. Illhealth is both a cause and consequence of homelessness. ${ }^{96}$ Homeless people experience significantly higher rates of death, disability and chronic illness than the general population but have less access to health services. ${ }^{97}$ Research and experience demonstrate that improving health outcomes for homeless people requires specifically targeted health care services, together with programs to address underlying causes of homelessness. ${ }^{98}$ Despite this, neither Australia nor

\footnotetext{
${ }^{94}$ SENATE COMMUNity AFFAIRS REFERENCES COMMITTEE, supra note 9, at 434 [Recommendation 94].

${ }^{95} \mathrm{Id}$. at 434.

${ }^{96}$ Lucy, supra note 18 , at 6.

${ }^{97}$ Harris, Sainsbury \& Nutbeam, supra note 21.

${ }^{98}$ Braveman and Gruskin, supra note 32, at 539, 540.
} 
Victoria has a homelessness action plan or adequately funded and appropriately targeted health care services for homeless people.

In my view, federal and state governments should develop a comprehensive homelessness and health action plan. This plan should establish coordinated programs, set timelines and guarantee expenditure to improve public health by addressing and ending homelessness. Under the plan, governments should substantially increase funding to improve the availability and accessibility of targeted, specialist health care services for people experiencing homelessness.

\section{Adequate and Effective Protection from Discrimination}

As discussed above, there are also strong links between discrimination and ill health. ${ }^{99}$

The right to equality and freedom from discrimination is an integral component of the international human rights normative framework, including the right to the highest attainable standard of health and health services. ${ }^{100}$ Despite this, discrimination against people experiencing homelessness, unemployment or poverty, including in health and medical services, is widespread but lawful in Australia and Victoria. At a state level, for example, the Equal Opportunity Act 1995 (Vic) does not prohibit discrimination on the ground of social status, homelessness, poverty, unemployment or on the basis that a person is a recipient of social security or welfare assistance. This lack of legal protection from discrimination causes and contributes to homelessness, poverty and poor public health outcomes.

In my view, it is imperative that the Victorian Parliament amend section 6 of the Equal Opportunity Act 1995 (Vic) to include 'social status' as an attribute on the basis of which discrimination is prohibited. Under section 4 of the Act, 'social status' should be defined to include a person's status of being 'homeless', 'unemployed' or 'a recipient of social security payments'.

At a federal level, the ICESCR should be scheduled to the Human Rights and Equal Opportunity Commission Act 1986 (Cth). This would empower the Commission to investigate and monitor the implementation of economic, social and cultural human rights that impact on public health. ${ }^{101}$

\footnotetext{
${ }^{99}$ Lisa Waller, Living with Hepatitis C: From Self-Loathing to Advocacy, 180 MediCAL JouRnal of AUSTRALIA 293 (2004).

${ }^{100}$ COMmitTeE ON ECONOMIC, SOCIAL AND CUltural RIGHTS, supra note 11, at 3. See also ICCPR ARTS 2(1) AND 26 AND ICESCR ART 2(2).

${ }^{101}$ See also Otto, supra note 46, at 11.
} 


\section{E Guaranteed Adequate Income}

According to Amartya Sen, Nobel Prize Winner for Economics, 'inadequate income is a strong predisposing condition for an impoverished life'. ${ }^{102}$ An adequate income is necessary to ensure an adequate standard of living, facilitate participation in the civil, political, economic, social and cultural aspects of community life, and to facilitate access to the highest attainable standard of health. Reflecting this, article 9 of the ICESCR provides that aall people have the right to social security. At its most basic, the implementation of this right requires that the Australian and Victorian Governments ensure that social security is available to cover all the risks involved in the loss of means of subsistence beyond a person's control. ${ }^{103}$

Although international human rights law does not prescribe social security payment levels, benefits must not be reduced below a minimum threshold. Social security must be sufficient to ensure a dignified human existence and to meet people's needs. A person's needs vary based on factors including housing status, age, health, cultural background, family responsibilities, and other factors. Recognising this, and in accordance with core obligations to ensure minimum essential standards, social security availability and payment levels must meet the special needs for assistance and other expenses often associated with homelessness and basic subsistence. ${ }^{104}$ Beyond this, governments must also devote the maximum of their available resources towards progressively ensuring an adequate income for everyone.

In line with Australia's international human rights commitments, it is imperative that Australia's social security regime be amended to ensure that social security payments are available to all people who experience a loss of income beyond their control or who require income support to ensure realisation of their human right to an adequate standard of living. Social security payments should be increased to levels above the Henderson Poverty Line so that recipients are able to meet their material needs and participate in society. Payments should be sufficient to ensure that recipients can afford adequate housing and an adequate standard of living.

Further to this, the breach penalty regime under the Social Security Act 1991 (Cth) should be amended so that people are only penalised if they wilfully and intentionally breach their mutual obligations. Penalties should be no longer than 8 weeks duration, no greater than 25 per cent of income and recoverable on compliance or reasonable steps.

Recognising the practical impediments to homeless people adducing sufficient proof of identity to access and maintain payments, Centrelink's 'proof of identity'

\footnotetext{
${ }^{102}$ SEN, supra note 11 , at 87.

${ }^{103}$ Committee on Economic, Social and Cultural Rights, General Comment 6: Economic SOCIAL AND CULTURAL RIGHTS OF OLDER PERSONS, UN DOC. HRI/GEN/1/REV.5, 43 (2001).

${ }^{104}$ COMmitTeE ON ECONOMIC, SOCIAL AND CUltural Rights, GENERAL COMMENT 5: PERSONS With DISABILITIES, UN DOC HRI/GEN/1/REV.5, 28 (2001).
} 
requirements should be changed so that homeless people can use a letter from a homelessness assistance service as proof of identity.

Finally, federal and state governments should develop an integrated package of social security assistance to homeless people that includes access to health care, adequate housing, employment assistance and personal support to ensure sustainable outcomes.

\section{CONCLUSION}

There are significant positive correlations between good public health and respect for and realisation of human rights.

The enshrinement of human rights principles in public health legislation and institutions provides a useful and important framework to identify, monitor, assess and address civil, political, economic, social and cultural determinants of health. The integration of human rights principles into health service development, implementation and delivery, focuses attention on the need for health services to be adequate, accessible, non-discriminatory and appropriately targeted. ${ }^{105}$

A human rights approach to public health requires that factors underlying poor health outcomes, including homelessness, poverty and discrimination, be identified and addressed through a range of legislative and institutional measures. It requires that these measures be concrete, targeted, progressive and, using the maximum available resources, directed to the full and expeditious realisation of the right to health and interconnected human rights, including the right to adequate housing, the right to social security, the right to non-discrimination, the right to participation, and the right to human dignity and respect.

Homelessness, poverty, discrimination and vulnerability to ill health would be significantly reduced if Australian governments took seriously their obligations to respect, protect and fulfill human rights.

\footnotetext{
${ }^{105}$ Gruskin, supra note 37 , at 1 .
} 